\title{
CYP2C9*8 Allele
}

National Cancer Institute

\section{Source}

National Cancer Institute. CYP2C9*8 Allele. NCI Thesaurus. Code C46015.

Human CYP2C9*8 allele is located within $10 \mathrm{q} 24$ and is approximately $33 \mathrm{~kb}$ in leng th. This allele, a variant form of the CYP2C9 wild-type allele, encodes cytochrome P450 2C9*8 protein. The CYP2C9*8 allele exhibits a clinically-relevant SNP (c.449G>A) in exon 3 that results in a $\mathrm{R} 150 \mathrm{H}$ coding change. This alteration in protein sequence increases the enzymatic activity of the cytochrome P450 2C9*8 protein. 